\title{
An Assessment of Omani Native Sheep Fiber Production and Quality Characteristics
}

\author{
Osman Mahgoub1*, Isam T. Kadim ${ }^{1}$, Ahmed Al-Dhahab1, \\ Reynaldo B. Bello², Issa S. Al-Amri' ${ }^{3}$, and Aisha A. Ambu Ali ${ }^{4}$ \\ and Samera Khalaf ${ }^{1}$
}

${ }^{1}$ Department of Animal and Veterinary Sciences, College of Agricultural and Marine Sciences, ${ }^{2}$ Agricultural Experiment Station, College of Agricultural and Marine Sciences,

${ }^{3}$ College of Medicine and Health Sciences, PO Box 35, Al-Khod 123, Sultanate of Oman, ${ }^{4}$ Department of Marine Sciences and Fisheries, College of Agricultural and Marine Sciences, PO Box 34, Al-Khod 123, Sultan Qaboos University, Sultanate of Oman

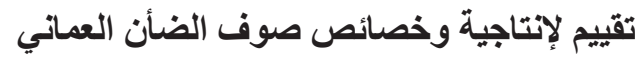

عثمان محجوب و عصام كاظم وأحمد الذهب ورينالدو بيلو وعيسى العامري وعائشة أمبوعلي وسميرة خلف

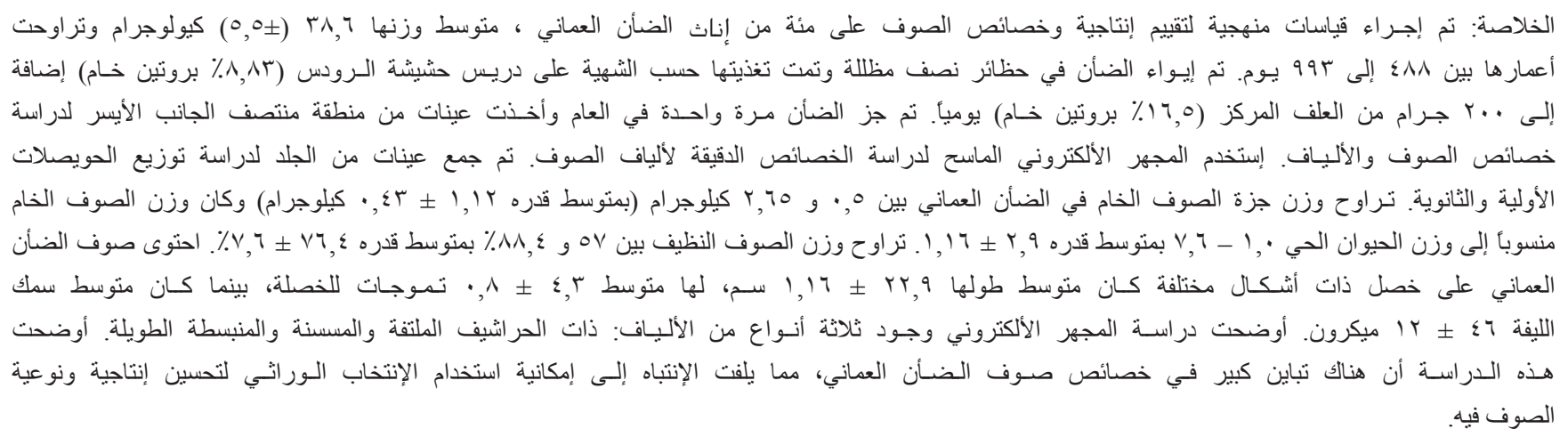

ABSTRACT: Wool production and quality measurements were carried out on 100 Omani native female sheep (body weight $38.6 \pm 5.5 \mathrm{~kg}$; age $993 \pm 488$ d). Sheep were kept in partially shaded pens and fed ad libitum Rhodes grass hay (crude protein $8.83 \%$ ) plus a daily amount of $200 \mathrm{~g}$ general ruminant concentrate (crude protein 16.5\% DM). Animals were shorn once a year and samples were taken from the left mid-side site to determine fleece and fiber characteristics. The scanning electron microscope (SEM) was used to study the fine appearance of the wool fibers. A skin sample was used to study the histological arrangement and number of secondary and primary follicles. The greasy fleece weight (GFW) in Omani sheep ranged between 0.50- $2.65 \mathrm{~kg}$ (mean $1.12 \pm 0.43 \mathrm{~kg}$ ) and the GFW expressed as a percentage of BW ranged between 1.0-7.6 with a mean of $2.9 \pm 1.16$. Clean wool yield in Omani sheep fleece ranged between 57.1 and $88.4 \%$ with a mean of $76.4 \pm$ 7.6. Omani sheep fleece contained various staple shapes and had a mean staple length of $22.9 \pm 1.16 \mathrm{~cm}, 4.3 \pm 0.8 \mathrm{crimps}$ per staple; and a mean fiber diameter of $46 \pm 12 \mu \mathrm{m}$. Electron microscopy revealed three types of fibers; wrap-around, angled type and polygonal and elongated scales. This study indicated a wide variation in the wool characteristics of Omani native sheep fleece, which suggested that selection may be employed to improve wool production and quality in these sheep.

Keywords: Oman, sheep, wool, fleece, assessment.

\section{Introduction}

Sheep are important animals worldwide for the provision of animal protein and wool. Their other products such as fiber, milk, skins or dung are also important as a source of income for small holders in the less developed parts of the world. Oman has 361,000 sheep, 1,018,000 goats, 320,000 cattle and 118,000 camels (Anonymous, 2005) with an estimated $3 \%$ annual increase in animal numbers. There is one major breed of sheep in Oman kept in small flocks by nomadic and semi-nomadic pastoralists as well as by smallholder in settled villages. Under almost all these conditions, sheep graze poorquality range grass and browse acacia shrubs and other trees, or they are feed Rhodes grass hay, dates, dried fish sardines, banana stems and household leftovers. Omani sheep, which are found over most of the northern parts of the country, are predominantly black but white sheep are not uncommon. They are thin-tailed (with slightly thicker base), small in size and unthrifty in appearance; males are mostly horned and females polled (Anonymous, 1978). The average adult live 
weight of Omani sheep raised under traditional systems range between 22 and $25 \mathrm{~kg}$ (Anonymous, 1978). Under intensive management, Omani sheep showed improved performance in the form of high growth rates and good carcass composition compared to those raised under traditional systems (Al-Nakib et al., 1996; Mahgoub and Lodge, 1994a, b).

In Oman, meat is the major product of sheep. Little milk is consumed but their fiber is used by Bedouins to make rugs, artifacts for household and racing camels. The local sheep are described as having coarse wool (Anon, 1978) although no studies have been carried out to determine their skin cover fiber quality. The objective of this study was to evaluate the production and quality characteristics of Omani sheep fiber.

\section{Materials and Methods}

\section{Animals}

Experimental measurements were carried out on 100 Omani native female sheep kept in the Agricultural Experiment Station of the College of Agricultural and Marine Sciences, Sultan Qaboos University. The sheep ranged in body weight between $29-51 \mathrm{~kg}$ (mean 38.6 $\pm 5.5 \mathrm{~kg}$ ) and age between 285-2072 d (mean $993 \pm 488$ d). Sheep were kept in partially shaded pens and fed $a d$ libitum Rhodes grass hay (DM 93.4\%; with CP 8.83\% $\mathrm{DM}$, crude fiber $41 \% \mathrm{DM}$, crude fat $1.8 \% \mathrm{DM}$ and ash $9.4 \% \mathrm{DM}$ ) plus a daily amount of $200 \mathrm{~g}$ general ruminant concentrate (DM 92.7\%; with CP 16.5\% DM, crude fiber $2.26 \%$ DM, crude fat $3.34 \% \mathrm{DM}$ and ash $5.9 \%$ DM). Water and mineral salt blocks were available ad libitum. Animals were subjected to routine animal health procedures including regular vaccination and deworming. Animals were weighed monthly.

\section{Fleece Measurements}

Sheep were shorn once a year using an electrical commercial shearing device with a hand piece. Greasy fleece weight was determined by weighing the fleece of sheep immediately after shearing on a digital scale. Prior to shearing, a sample was taken from the left mid-side site, over the last rib, using the same shearing device. The wool yield was determined by weighing a sample from the mid-side site in an aluminum tray. The sample was then hand-washed thoroughly using a commercial detergent then dried in an oven at $70^{\circ} \mathrm{C}$ for 24 hours. The tray plus sample were reweighed and the yield was computed as the difference in weight between greasy fleece weight and dry clean weight.

\section{Staple and Fiber Characteristics}

Mid-side site samples were used to study the fiber attributes in Omani sheep. Staple length was measured by carefully spreading the staple on a board and measuring it to the nearest $\mathrm{mm}$ from the cut base to the point at the tip where the bulk of fibers end using a ruler. The number of crimps was counted on each staple without maximum stretching.

Fiber diameter was determined using a microscope equipped with a caliper in the eyepiece, which was calibrated to a slide measure. A sub-sample of fibers was taken randomly and fitted to a microscope slide and fixed with a tape. The width of twenty fibers from each sample was measured at the middle of the fiber.

\section{Histology}

Skin samples were taken from the right mid-side site (over the last rib) from 16 Omani sheep to study follicle structure while the sheep were controlled in the lateral recumbence position. The wool was clipped and the area disinfected with a multipurpose disinfectant. A shot of a local anesthetic was given and a circle of $5 \mathrm{~mm}$ diameter was made using a circular stainless steel cutter. Scalpel blade and forceps were used to remove the skin sample, which was fixed in $10 \%$ buffered formalin for histology. Blocks were prepared, sectioned and stained with haematoxlin/ eosin stain to enable studying the arrangement of primary and secondary follicles.

\section{Electron Microscopy}

The scanning electron microscope was used to study the cuticle scale pattern of wool fibers. About 10-15 fibers of about $1 \mathrm{~cm}$ length from each sample were cleaned in graded ethanol dilutions $(25,50,75,90$ and $3 \times 100 \%$, $10 \mathrm{~min}$ each). They were blotted dry in filter paper then mounted in stubs. The fibers were placed in Sputter coater, coated with gold particles for $1 \mathrm{~min}$, and viewed with JEOL JSM-5600LV Scanning Electron Microscope.

\section{Results and Discussion}

\section{Wool Production Characteristics}

The GFW in Omani sheep ranged between 0.50-2.65 kg with a mean of $1.12 \pm 0.43 \mathrm{~kg}$ (Table 1). This weight is within the range for tropical and sub-tropical sheep reported by Gatenby (1986) but is well below that of specialized wool-producing breeds with GFW of about 4-5 kg. Tabbaa et al. (2001) reported a GFW of $2.1 \mathrm{~kg}$ in $53 \mathrm{~kg}$ Awassi sheep and a range of 1.2-1.9 kg GFW for other Middle East carpet wool sheep. Awassi is a major multipurpose sheep in the Middle East and, in Jordan fleeces were estimated to represent about $2.5 \%$ of the value of products from its commercial production beside meat and milk.

The frequency distribution of the GFW is presented in Figure 1. It represents a normal distribution bell curve slightly skewing to the left. The curve indicates that it is possible to improve wool yield in Omani sheep by exploiting the elite group at the right end (with more than 2 $\mathrm{kg} \mathrm{GFW)} \mathrm{to} \mathrm{improve} \mathrm{the} \mathrm{average} \mathrm{through} \mathrm{selection} \mathrm{because}$ of the high heritability score for the GFW. Ghoneim et al. (1974) reported that the heritability score for fleece weight in Awassi Iraqi sheep was 0.47 by paternal half- 
Table 1. Omani sheep wool production parameters.

\begin{tabular}{|c|c|c|c|c|c|}
\hline $\begin{array}{l}\text { Statistical } \\
\text { Function }\end{array}$ & Body weight (kg) & Age (days) & $\begin{array}{l}\text { Greasy fleece } \\
\text { weight }(\mathrm{kg})\end{array}$ & Yield (\%) & $\begin{array}{c}\text { Greasy fleece } \\
\text { weight/body weight }\end{array}$ \\
\hline Mean & 38.63 & 993.29 & 1.12 & 76.41 & 2.94 \\
\hline SD & 5.49 & 488.30 & 0.43 & 7.56 & 1.16 \\
\hline Maximum & 51.00 & 2072.00 & 2.65 & 88.42 & 7.79 \\
\hline Minimum & 29.00 & 285.00 & 0.50 & 57.14 & 1.04 \\
\hline Median & 38.00 & 956.50 & 1.03 & 77.18 & 2.70 \\
\hline Mode & 39.00 & 300.00 & 0.70 & NA & 2.70 \\
\hline
\end{tabular}

sib correlation and 0.16 by regression of offspring on dam. Repeatability was 0.32 by intraclass correlation and 0.36 by correlation between pairs of records. The authors recommended that for improvement of fleece weight, breeding stock should be selected for fleece weight at first shearing when they are $18 \mathrm{~m}$ old.

To overcome the effects of the wide range of body weight in animals used in the present study, GFW was expressed as a percentage of BW and it ranged between 1.04 and 7.56 with a mean of $2.94 \pm 1.16 \mathrm{~kg}$ (Figure 2). This is higher than $2.2 \mathrm{~kg}$ GFW adjusted for BW in yearling Awassi sheep (Tabbaa et al., 2001). There was a trend oft fleece weight in $\mathrm{kg}$ or as a percentage of body weight, to increase with age with a maximum of $1.5 \mathrm{~kg}$ in $1267 \mathrm{~d}$ old sheep then slightly decreased to about $1.0 \mathrm{~kg}$ by the $1908 \mathrm{~d}$ group of age (Figure 2). Similarly, Tabbaa et al. (2001) found that GFW was higher in yearling Awassi sheep than in lambs but there was no difference between yearling and mature sheep in GFW. Ghoneim et al (1974) reported that sex, age, year of shearing and type of birth significantly affected fleece weight. The fleece weight was the highest at the first and second shearings.

Yield in Omani sheep fleece ranged between 57.14 and $88.42 \%$ with a mean of $76.4 \pm 7.56$ (Table 1 ). This yield is comparable to that of 74-62\% reported for tropical and subtropical sheep by Gatenby (1986).

The majority of Omani sheep are black since black is a dominant color in Omani sheep. However, some white Omani sheep are also available and there are breeding programs for their improvement in breeding stations in the country (Dr Tag Elsir Issa, personal communications). Such programs would be beneficial for improvement of Omani sheep wool production.

\section{Fleece Characteristics}

The mid-side site position over the last rib was reported to be closely representative of both follicle and wool characteristics and therefore, much used in sampling (Gatenby, 1986). This site has been used for assessing Omani sheep fleece characteristics in the present study.

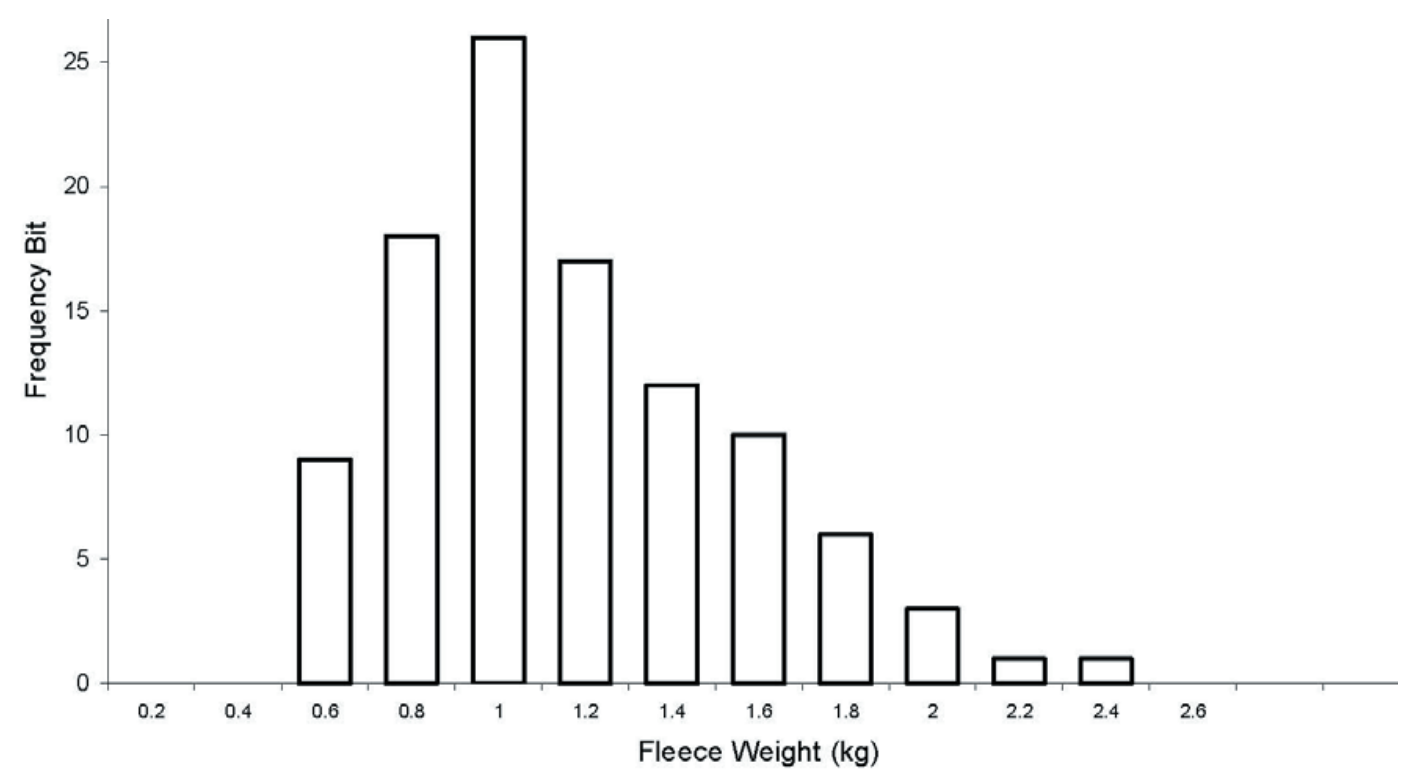

Figure 1. Frequency distribution of the greasy fleece weight in Omani sheep. 


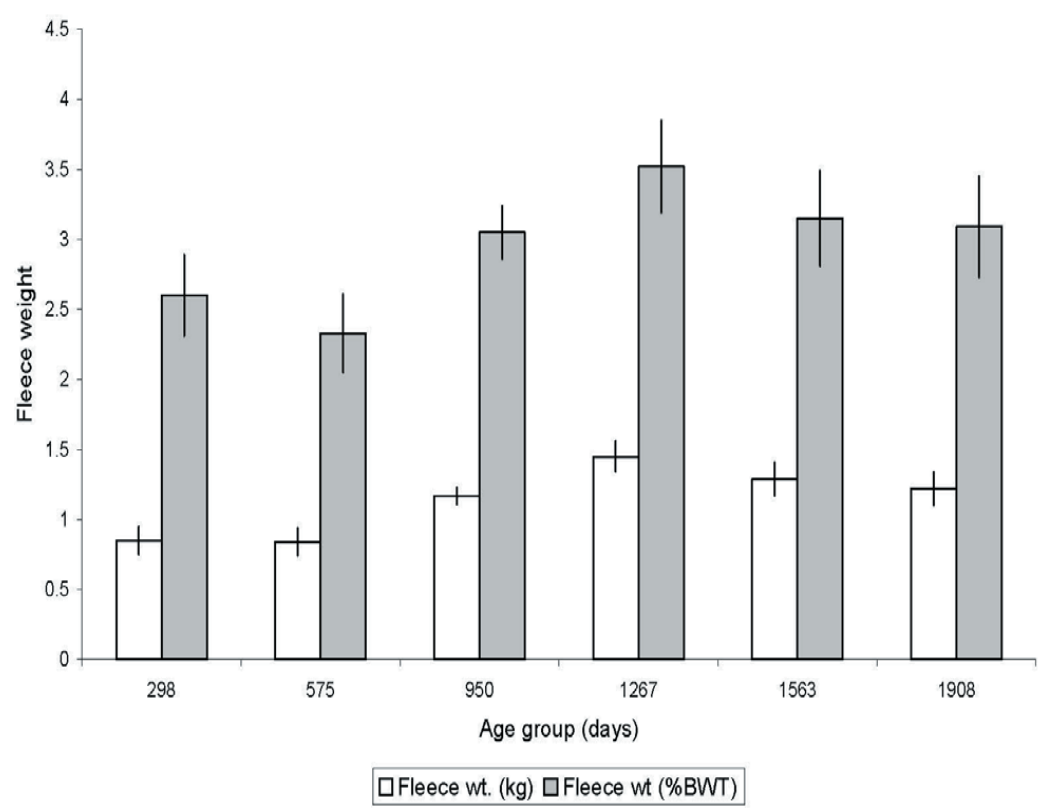

Figure 2. Fleece weight $(\mathrm{kg})$ and fleece weight as percentage of body weight expressed on various age groups of Omani sheep.

There were different staple shapes in Omani sheep fleece (Figure 3) ranging from rectangular aggregate of small staples to oval, but most had pointed tips. Sheep producing coarse wool usually have more tippy staples.

Staple length in Omani sheep fleece ranged between $12-37 \mathrm{~cm}$ with a mean of $22.86 \pm 4.31 \mathrm{~cm}$ (Table 2). This indicates that fleece from local sheep is longer than that reported for most tropical and subtropical sheep (Gatenby, 1986). Tabbaa et al. (2001) reported a staple length of $14 \mathrm{~cm}$ in Awassi sheep. The number of crimps ranged between 2-6 (mean 4.30 \pm 0.80 ) indicating that the fleece of native Omani sheep is more straight than curly. Because

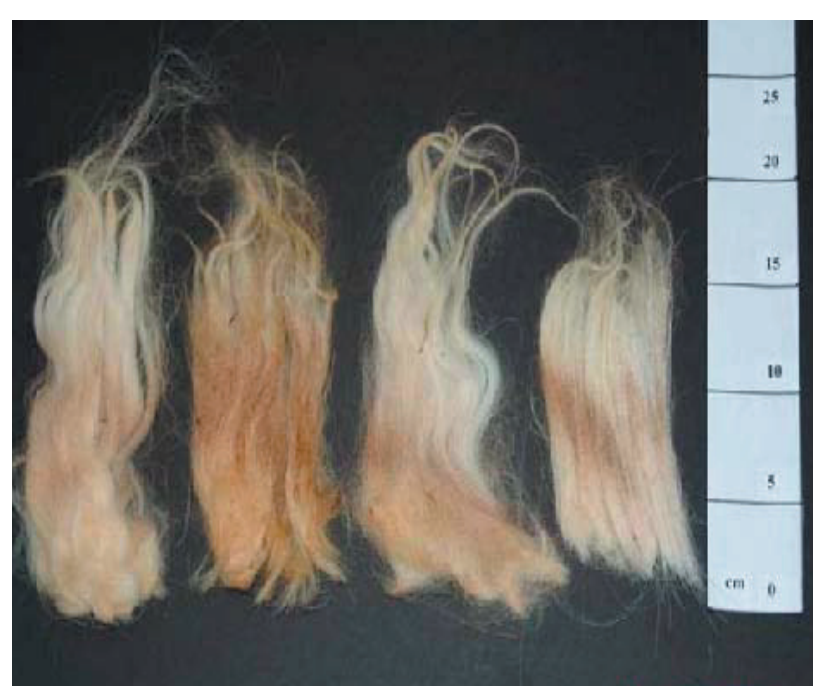

Figure 3. Three different types of Omani sheep fleece. of its crimp, or curl, wool has considerable resilience and with its high tensile strength and elasticity, gives fine woolen fabrics the ability to retain shape better than cloth made from other natural fibers. The length of Omani sheep wool is much longer than that reported for carpet wool breeds $(4-12 \mathrm{~cm})$ and more similar to that of English long lustrous wool (Dr. M. Salehi, personal communication, 2008).

The fiber diameter in Omani sheep is presented in Table 2. It ranged between 24-67.5 $\mu \mathrm{m}$ (mean $45.9 \pm 12.26$ $\mu \mathrm{m})$. This ranks it among the carpet wool-producing sheep (Gatenby, 1986). Tabbaa et al. (2001) reported a fiber diameter of $36 \mu \mathrm{m}$. Shepherd (1959, cited by Gatenby, 1986) indicated that the range of fiber diameter for carpet wool should be $11-90 \mu \mathrm{m}$ with $85 \%$ of the fibers in the range of 21-60 $\mu \mathrm{m}$. According to Dr Salehi (personal communication, 2008), the diameter range of fibers in carpet wools range between 11-90 $\mu \mathrm{m}$. The wide range in fiber diameter in Omani sheep indicates a wide variation, which may be exploited using selection to improve the fineness of wool in these sheep. Average fiber diameter is a trait with high heritability score of $0.45-0.60$ (Beatson, 1988 ) renders it rapidly responding for efficient selection programs.

Carpet wools consist of a mixture of true wool, hair, heterotypical and kemp fibers. The morphology, microscopy and dimension of each fiber types in carpet wool are different. The average diameter of carpet wools is between $25-35 \mu \mathrm{m}$ in unimproved and native breeds in Middle East or Asian countries and between 35-45 um in improved carpet wool in New Zealand and (Dr M. Salehi, personal communication ,2008). More detailed studies are needed to determine fleece characteristics of Omani sheep 
Table 2. Characteristics of Omani sheep wool.

\begin{tabular}{|c|c|c|c|c|c|c|c|}
\hline $\begin{array}{l}\text { Statistical } \\
\text { Function }\end{array}$ & $\begin{array}{l}\text { Staple length } \\
(\mathrm{cm})\end{array}$ & $\begin{array}{l}\text { Number of } \\
\text { crimps }\end{array}$ & $\begin{array}{l}\text { Number of } \\
\text { crimp/cm }\end{array}$ & $\begin{array}{l}\text { Fiber diameter } \\
\qquad(\mu \mathrm{m})\end{array}$ & $\begin{array}{c}\text { No of } \\
\text { Primary } \\
\text { follicles }\end{array}$ & $\begin{array}{c}\text { No of } \\
\text { secondary } \\
\text { follicles }\end{array}$ & Sec/Prim \\
\hline Mean & 22.86 & 4.30 & 0.19 & 45.9 & 22.9 & 12.8 & 0.6 \\
\hline SD & 4.31 & 0.80 & 0.03 & 12.26 & 8.2 & 10.5 & 0.4 \\
\hline Maximum & 37.00 & 6.00 & 0.29 & 67.50 & 43 & 40 & 1.6 \\
\hline Minimum & 12.00 & 2.00 & 0.12 & 24.00 & 1 & 0 & 0 \\
\hline Median & 23.00 & 4.00 & 0.18 & 45.25 & 22 & 10.5 & 0.51 \\
\hline Mode & 23.00 & 4.00 & 0.17 & 45.50 & 22 & 11.5 & 0.53 \\
\hline
\end{tabular}

using larger numbers of animals with separation of fibers to determine the percentage of each fiber type.

\section{Fiber Structure}

The outer surface of wool fiber enables it to be differentiated from hair mainly by the nature of the scales that cover the fiber. Wool scales are numerous, minute, and pointed and are attached only at their bases causing interlock under pressure. The number of scales varies with the fineness and curliness of the fiber. Accordingly, micrographs taken for the Omani sheep fibers indicate that they look like fairly typical wool rather than hair fibers (Figure 4). The micrographs also showed that there were three different wool fiber types available in Omani sheep similar to those described by Woods and Orwin (1982) and shown in Figure 4. The first type is a wrap-around scale pattern on keratinized wool fiber which is usually seen in fine wool fibers such as Merino (Dr Joy Wood, personal communication). Scales in Omani sheep of this type appears to be more numerous and pointed than in Woods and Orwin (1982) study. The second fiber type is the angled type of scale pattern which occur in medium diameter fibers. The angles of the Omani sheep scales are not as steep as for those reported by Woods and Orwin (1982). The third type of fiber is the polygonal and elongated scale pattern type which usually occurs in coarse fibers. This is mainly observed in large-diameter fibers as for Woods and Orwin (1982).

Wool follicle arrangement (primary and secondary) determines wool characteristics. Primary follicles give rise to coarser wool whereas secondary follicles give rise to true finer wool. Ratio of primary (occurs in trios) to secondary follicles determines wool density and fineness with Merinos having 15-25 of sec/prim ratio, Omani sheep (Table 2) would therefore have very coarse wool with a minimum number of primary and secondary follicles as well as low secondary/primary ratio. In specialized fine wool breeds such as the Merino, primary follicles are arranged in the form of three "trios". Other arrangements such as line and rectangular, are also observed in coarser wool breeds. Omani sheep follicles are arranged in line with very few secondary follicles (Figure 5).

\section{Potential of Wool Production from Omani Sheep}

Although it may currently appears to be a product of less significance, wool production from Omani native sheep may be improved as an extra source of income to farmers. Gatenby (1986) pointed out two major economical advantages of wool production in the tropics. First, there is no antagonism between meat and wool production, as the increase in body sizes tends to increase fleece weight. Second, wool production can be economical in arid areas

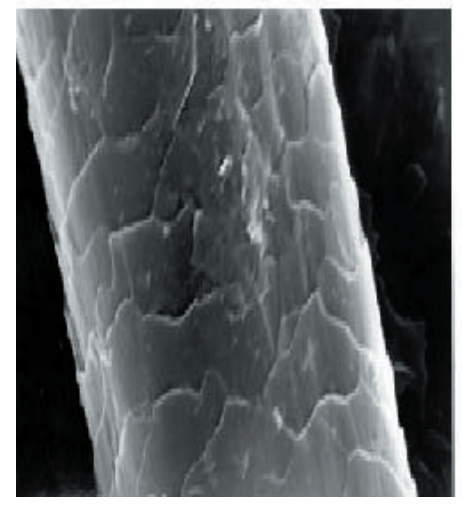

Wrap-around scale
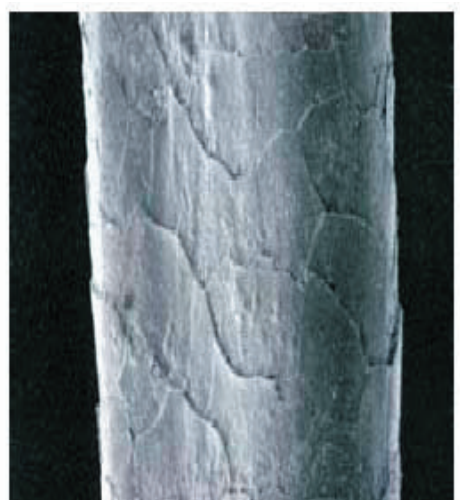

Angled type

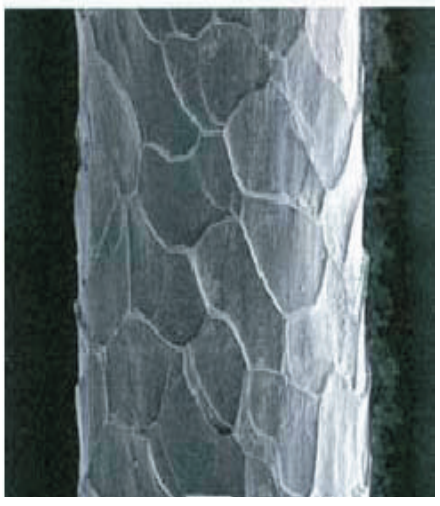

Polygonal \& elongated

Figure 4. Micrographs showing various types of wool fiber structure in Omani native sheep. 


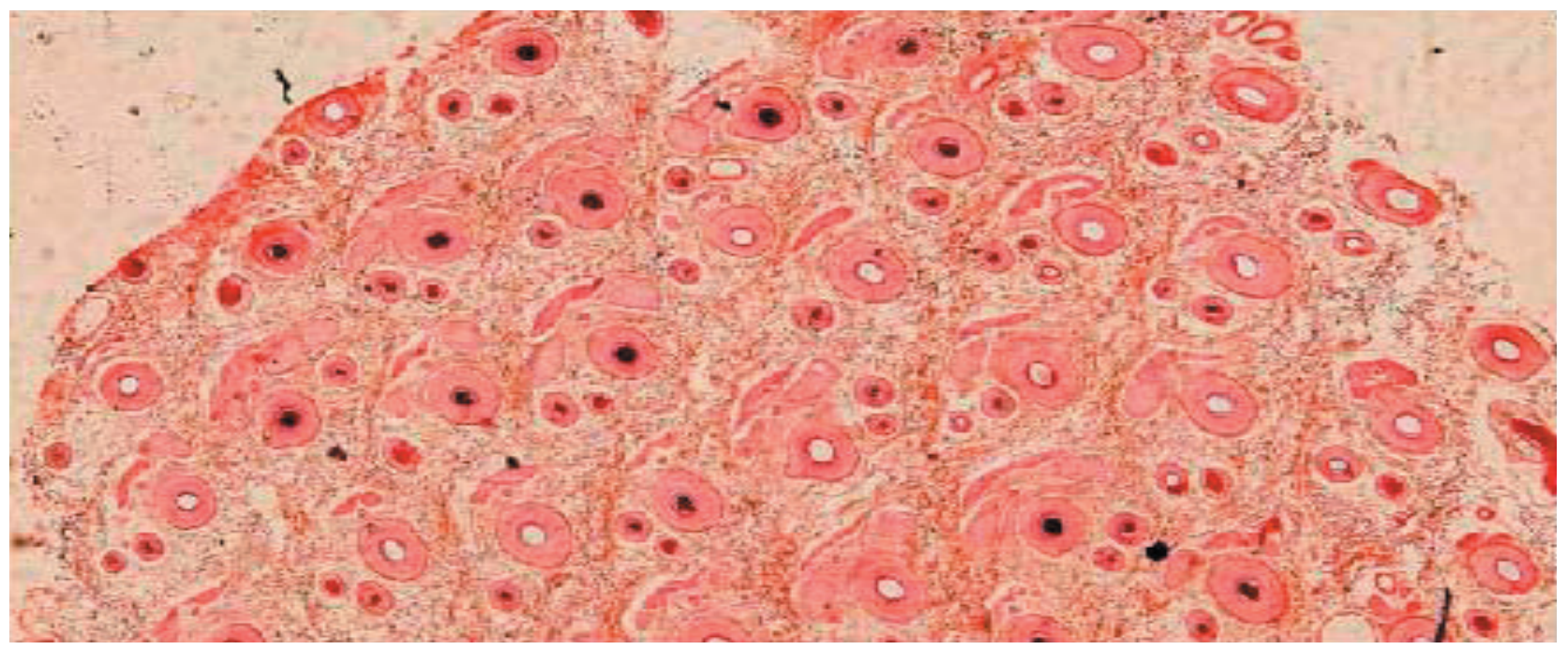

Figure 5. Histological section of Omani sheep skin showing the arrangement of primary and secondary fibers.

with meager nutritional resources, as wool can grow even if sheep are losing weight. It is understood that in order to improve the wool industry, attention should be paid not only to genetical improvement of sheep, but also to improved management, nutrition, shearing operations, handling and storage of wool. To improve fleece quality characteristics experts may assess wool on living animals by visual appraisal and without sophisticated methods. Therefore, Omani natives may be trained to do on-farm assessment of promising wool-producing animals. There are some individual sheep selected for their pure white color and finer fibers at Wadi Qurayat Breeding Center (Dr. Tagelsir Ali, personal communication). Such sheep would be more suited for improved wool production in Oman. Improvement of fineness of wool is important but it should be taken into consideration that there is a negative relationship between wool quantity and quality as wool weight per unit of metabolic live weight significantly decreases with decreasing mean fiber diameter (Saul et al., 1993).

\section{Acknowledgement}

The authors would like to thank Dr. Joy L Woods, Wool Fibre Science and Protein Chemistry Group, Wool Research Organization of New Zealand (Inc.), for advice on identification of fibre types. Thanks are due to Wadi Qurayat Research Station, Ministry of Agriculture, Oman, for help with sampling.

\section{References}

Al-Nakib, F.M.S., E.S.S. Al-Shukaily, S.S.S. AlHanai and S.A.M. Al-Nabhani. 1996. Comparative performance of Omani goats and sheep. Journal of Agricultural Science, Cambridge, 127:117-121.

Anonymous. 1978. Livestock Sector Review and Project Identification Final Report, Vol. 1. The Sector Review. A Report prepared for Oman Ministry of Agriculture and Fisheries by Hunting Technical Services Ltd. and the Sudanese Investment and Consultations Co. Ltd. Muscat, Oman 103pp.

Anonymous. 2002. Statistical Year Book 2002. Ministry of Agriculture and Fisheries, Muscat, Sultanate of Oman (Unpublished), 87pp.

Beatson, P. 1988. The Theory of Genetic Improvement. In: Wool Production and Preparation for Profit. R.H. Sanderson, D.J. Cottle and L.F. Story (Editors), 35-37. Lincoln College Wool Bulletin No.3. Lincoln College, New Zealand.

Gatenby, R.M. 1986. Sheep Production in the Tropics and the Sub-Tropics. Longman, New York, USA. 351pp.

Ghoneim, K.E., A.H. Taha, N.T. Kazzal and R.K.Abdallah. 1974. Effects of non-genetic factors and estimation of genetic parameters on fleece weight of Awassi sheep in Iraq. Tropical Agriculture (Trinidad) 51:51-56.

Mahgoub, O. and G.A. Lodge. 1994a. Growth and body composition of Omani local sheep. 1. Live-weight growth and carcass and non-carcass characteristics. Animal Production 58:365-372.

Mahgoub, O. and G.A. Lodge. 1994b. Growth and body composition of Omani local sheep. 2. Growth and distribution of musculature and skeleton. Animal Production 58:373-379.

Orwin, D.F.G. and J.L. Woods. 1982. The effects of within-fibre diameter variability and other fibre characteristics on the luster of wool. Journal of the Textile Institute 74:118-130.

Saul, G.R., A.J.F. Russell and A.R. Sibbald. 1993. Potential of different sheep breeds to improve wool production on UK hill and upland sheep farms. Small Ruminant Research 11:1-9.

Tabbaa, M.J., W.A. Al-Azzawi and D. Campbell. 2001. Variation in fleece characteristics of Awassi sheep at different ages. Small Ruminant Research 41:95-100.

Woods, J.L. and D.F.G. Orwin. 1982. The cytology of scale pattern formation in the wool follicle. Journal of Ultrastructural Research 80:230-242. 